\title{
HEAVY METALS CONTENT IN THE SOIL OF THE OSOGOVO MOUNTAIN
}

DOI: http://dx.doi.org/10.18509/GBP.2020.07

UDC: 550.42:546.81]:504.5(497.2)

\author{
Rumen Penin \\ Dimitar Zhelev \\ Department of Landscape Ecology and Environmental Protection, Faculty of Geology and \\ Geography, Sofia University “St. Kliment Ohridski”, Bulgaria
}

\begin{abstract}
The article is dedicated to the ore mining footprint on the environment of Osogovo Mountain in terms of heavy metals' content in the landscapes. Some of the mountain landscapes have been damaged by mining activities in the second half of 20th century and the landscapes have responded to this through change of the geochemical structure. The geochemical status of the landscapes is evaluated on the basis of own field and laboratory research of the territory - collecting soil samples, geochemical analysis, drawing geochemical spectrums and interpretation. The investigated elements are $\mathrm{Cu}, \mathrm{Zn}$, $\mathrm{Ni}, \mathrm{Mn}, \mathrm{Co}, \mathrm{Cr}$, and $\mathrm{Pb}$. The heavy metals' content in the selected landscapes is identified. In addition, the identified geochemical background of the mountain is compared with some neighboring mountainous areas and the major rock types in Bulgaria. The depicted geochemical status of soils as the focal point of the landscapes in the Osogovo Mountain displays the significant human impact on the environmental status of the mountain and potential threat to the health and life of people.
\end{abstract}

Keywords: landscapes, human impact, contamination, mining, geochemistry

\section{INTRODUCTION}

The complicated and unfriendly geopolitical relations between Bulgaria and the neighbouring Yugoslavia and Greece caused the isolation of the border areas (in South West Bulgaria) from the active manmade impact on the environment almost for the whole $20^{\text {th }}$ century. The processes of human depopulation became more intensive in the middle of the previous century. The lack of people forced recovery for many of the mountain landscapes in terms of vegetation and wildlife but not for all.

Even almost depopulated, the Bulgarian part of the Osogovo Mountain was an object of massive human impact caused by mining. The lead and zinc-rich ores in the mountain's petrography were the reason the government to start mineral extraction. This activity was as an economic act as well as an environmental damage. Even the financial collapse of the state-owned mining company operating in the mountain triggered the end of the mining (in the end of the last century) the geochemical footprint on the landscapes is still there. The environmental status of the mountain territory (in Bulgaria) has been investigated by geographers from Sofia University (2011-2018). The landscapes in the Osogovo Mountain (including soils, plants, and river sediments) have been researched for contamination with heavy metals. The presented work is a follow-up article of a longterm geochemical research of the landscapes in South West Bulgaria since 1989 [5, 6, $15]$. 


\section{METHODOLOGY}

The geochemical research of the landscapes allows scientists to approach a lot of ongoing environmental (and social) issues. They are a tool for monitoring of nature.

The methodological base of this investigation is the (geo)system approach [11, 7]. It is conducted through the analysis of chemical elopements' content in the landscape components and the relation between neighbouring landscapes. The soil is a focal point of the landscape where all processes are "printed" and "saved" because of its property to absorb substances. The geochemical research of soil evaluates its chemical properties and there for is an environmental indicator. The lack or the overconcentration of elements may be a sign of human impact that has damaged the environment.

The chemical elements' content in the various rocks and soils does not match lithospheric clarke (the average chemical element's content in the lithosphere). That is why the coefficient of clarke concentration (CC) is used as a way of outlining the abundance or the lack of particular elements in rocks and soils. It is the proportion between the chemical element's content in a particular natural component (Ci) such as a rock, soil, water, plants, etc. and the lithospheric clarke (C). The $\mathrm{CC}$ value could be equal to 1 or bigger $(\mathrm{CC}=>$ 1). If it is bigger that means that there is concentration of a particular chemical element in comparison to the average in the lithosphere. If $\mathrm{CC}$ is less than $1(\mathrm{CC}<1)$ the means that there is clarke dispersion (CD) of a particular chemical element in comparison to the average in the lithosphere.

Both CC and CD are used for interpretation of the geochemical analysis of soil samples collected in representative landscapes during a field trip in the Osogovo Mountain (2018). These two indicators are displayed by geochemical spectrums. The selected association of chemical elements includes $\mathrm{Cu}, \mathrm{Pb}, \mathrm{Zn}, \mathrm{Ni}, \mathrm{Co}, \mathrm{Cr}$, and $\mathrm{Mn}$.

The collected soil samples are chemically analyzed in the Geochemistry Laboratory of Sofia University. They are dried, quartered, levigated in porcelain cup, and sift through $63 \mu \mathrm{m}$, burned at $500^{\circ} \mathrm{C}$, and dissolved by a mixture of acids $\left(\mathrm{HClO}_{4}, \mathrm{HF}\right.$, and $\left.\mathrm{HCl}\right)$. The heavy metals content in the chemical solution is obtained by the method of atomicabsorption spectrometry (Perkin-Elmer 3030). The $\mathrm{pH}$ values are derived from water solution at ratio soil:water 1:2,5 after period of 18 hours.

\section{RESULTS AND INTERPRETATION}

The results of geochemical analysis of the soil samples for the content of heavy metals (a selected association) is displayed in Table 1.

The study encompasses the hypsometry between 1280 and $2251 \mathrm{~m}$. The microelement chemical content of the soil types of Cambisols and Umbrosols is found. A comparison of the heavy metals content is made between the geochemical status of the Osogovo Mountain and other geographical areas (including some neighboring mountains in Bulgaria) (Table 2). Based on this data a set of geochemical spectrums is drawn.

An important element of the interpretation is the consideration of the bedrock chemistry and its influence over the microelement content of the soils. In many cases, especially in the so-called natural background areas, this correlation is the most important for the radial differentiation of heavy metals in the soil profile. The average content of some microelements in the rock types in the Osogovo Mountain are outlined in Table 3 [3]. The dominant rock complexes the mountain are either igneous rocks from the Osogovo granitoid pluton (Oligocene) or metamorphic rocks such as mica schists (Miocene) and gneisses and amphibolites (Oligocene). 
Table 1. Content of heavy metals in the soils for the Osogovo Mountain (in Bulgaria)

\begin{tabular}{|c|c|c|c|c|c|c|c|c|c|}
\hline Landscape and soil type & Location & $\mathbf{C u}$ & $\mathbf{Z n}$ & $\mathbf{P b}$ & Mn & $\mathbf{N i}$ & Co & $\mathrm{Cr}$ & pH \\
\hline $\begin{array}{l}\text { Beech forest, left bank of } \\
\text { river Eleshnitsa, }(0-10 \mathrm{~cm}) \text {, } \\
\text { Cambisols }\end{array}$ & $\begin{array}{l}42^{\circ} 8^{\prime} 20^{\prime \prime} \mathrm{N} \\
22^{\circ} 33^{\prime} 58^{\prime \prime} \mathrm{E} \\
1300 \mathrm{~m}\end{array}$ & 380 & 144 & 62 & 586 & 11 & 28 & 18 & 5 \\
\hline $\begin{array}{l}\text { Beech forest, left bank of } \\
\text { river Eleshnitsa, }(30-40 \mathrm{~cm}) \text {, } \\
\text { Cambisols }\end{array}$ & $\begin{array}{l}42^{\circ} 8^{\prime} 20^{\prime \prime} \mathrm{N} \\
22^{\circ} 33^{\prime} 58^{\prime \prime} \mathrm{E} \\
1300 \mathrm{~m}\end{array}$ & 266 & 104 & 71 & 386 & 120 & 19 & 19 & 5 \\
\hline $\begin{array}{l}\text { Beech forest, left bank of } \\
\text { river Eleshnitsa, }(70-80 \mathrm{~cm}) \text {, } \\
\text { Cambisols }\end{array}$ & $\begin{array}{l}42^{\circ} 8^{\prime} 20^{\prime \prime} \mathrm{N} \\
22^{\circ} 33^{\prime} 58^{\prime \prime} \mathrm{E} \\
1300 \mathrm{~m}\end{array}$ & 69 & 69 & 53 & 621 & 85 & 12 & 20 & 6 \\
\hline $\begin{array}{l}\text { Ridge of mountain, near } \\
\text { Shapka Peak, }(0-10 \mathrm{~cm}) \text {, } \\
\text { Umbrosols }\end{array}$ & $\begin{array}{l}42^{\circ} 10^{\prime} 52^{\prime \prime} \mathrm{N} \\
22^{\circ} 34^{\prime} 19^{\prime \prime} \mathrm{E} 1 \\
860 \mathrm{~m}\end{array}$ & 19 & 73 & 51 & 232 & 31 & 13 & 28 & 5 \\
\hline $\begin{array}{l}\text { Beech forest "Tsarna Reka" } \\
\text { reserve, }(0-10 \quad \mathrm{~cm}), \\
\text { Cambisols }\end{array}$ & $\begin{array}{l}42^{\circ} 9^{\prime} 49^{\prime \prime} \mathrm{N} \\
22^{\circ} 33^{\prime} 35^{\prime \prime} \mathrm{E} \\
1600 \mathrm{~m}\end{array}$ & 18 & 159 & 70 & 749 & 74 & 11 & 25 & 5 \\
\hline $\begin{array}{l}\text { Ridge of mountain }- \text { a } \\
\text { watershed } \\
\text { catchments of river Tsarna } \\
\text { and river Eleshnitsa, }(0-10 \\
\mathrm{cm}), \text { Umbrosols }\end{array}$ & $\begin{array}{l}42^{\circ} 9^{\prime} 28^{\prime \prime} \mathrm{N} \\
22^{\circ} 33^{\prime} 14^{\prime \prime} \mathrm{E} \\
1920 \mathrm{~m}\end{array}$ & 46 & 156 & 111 & 552 & 99 & 18 & 209 & 5 \\
\hline $\begin{array}{l}\text { Mixed deciduous forest in the } \\
\text { valley of } \begin{array}{l}\text { Kyustendilska } \\
\text { Bistritsa, } \\
\text { Cambisols }\end{array}\end{array}$ & $\begin{array}{l}42^{\circ} 12^{\prime} 13^{\prime \prime} \mathrm{N} \\
22^{\circ} 32^{\prime} 45^{\prime \prime} \mathrm{E} \\
1280 \mathrm{~m}\end{array}$ & 20 & 151 & 58 & 236 & 17 & 7 & 22 & 5 \\
\hline $\begin{array}{l}\text { Mixed deciduous forest in the } \\
\text { valley of Kyustendilska } \\
\begin{array}{lll}\text { Bistritsa, } & (20-30 & \mathrm{cm}), \\
\text { Cambisols } & & \end{array}\end{array}$ & $\begin{array}{l}42^{\circ} 12^{\prime} 13^{\prime \prime} \mathrm{N} \\
22^{\circ} 32^{\prime} 45^{\prime \prime} \mathrm{E} \\
1280 \mathrm{~m}\end{array}$ & 22 & 96 & 73 & 195 & 27 & 9 & 24 & 5 \\
\hline $\begin{array}{l}\text { Mixed deciduous forest in the } \\
\text { valley of } \begin{array}{l}\text { Kyustendilska } \\
\text { Bistritsa, } \\
\text { Cambisols }\end{array}\end{array}$ & $\begin{array}{l}42^{\circ} 12^{\prime} 13^{\prime \prime} \mathrm{N} \\
22^{\circ} 32^{\prime} 45^{\prime \prime} \mathrm{E} \\
1280 \mathrm{~m}\end{array}$ & 49 & 185 & 703 & 441 & 75 & 7 & 20 & 6 \\
\hline $\begin{array}{l}\text { Peak Ruen, }(0-10 \quad \mathrm{~cm}) \text {, } \\
\text { Umbrosols }\end{array}$ & $\begin{array}{l}42^{\circ} 15^{\prime} 80^{\prime \prime} \mathrm{N} \\
22^{\circ} 51^{\prime} 63^{\prime \prime} \mathrm{E} \\
2251 \mathrm{~m}\end{array}$ & 26 & 126 & 154 & 573 & 117 & 7 & 27 & 4 \\
\hline $\begin{array}{l}\text { Near a tailings dam, }(0-10 \\
\mathrm{cm}) \text {, Anthropo-genic soil } \\
\text { substrate }\end{array}$ & $\begin{array}{l}42^{\circ} 14^{\prime} 12^{\prime \prime} \mathrm{N} \\
22^{\circ} 28^{\prime} 15^{\prime \prime} \mathrm{E} \\
930 \mathrm{~m}\end{array}$ & 92 & 138 & 1656 & 1018 & 62 & 2 & 3 & 3 \\
\hline
\end{tabular}


Table 2. Average content of heavy metals in selected areas $(\mathrm{mg} / \mathrm{kg})$

\begin{tabular}{|c|c|c|c|c|c|c|c|}
\hline Area & $\mathrm{Cu}$ & $\mathrm{Zn}$ & $\mathrm{Pb}$ & Mn & $\mathrm{Ni}$ & Co & $\mathrm{Cr}$ \\
\hline Lithosphere & 47 & 83 & 16 & 1000 & 58 & 18 & 83 \\
\hline Soils of world ${ }^{[16]}$ & 20 & 50 & 10 & 850 & 40 & 8 & 100 \\
\hline Soils of Europe ${ }^{[12]}$ & 17 & 68 & 33 & 810 & 37 & 10 & 95 \\
\hline Soils of Bulgaria ${ }^{[4]}$ & 30 & 75 & 35 & 1000 & 36 & 20 & 70 \\
\hline $\begin{array}{l}\text { Soils of } \\
\text { (natural background })^{[8]}\end{array}$ & 24 & 67 & 25 & 695 & 32 & 16 & 60 \\
\hline Soils of Vlahina Mountain ${ }^{[14]}$ & 12 & 350 & 21 & 688 & 123 & 41 & 74 \\
\hline Soils of Maleshevska Mountain ${ }^{[13,15]}$ & 27 & 94 & 26 & 304 & 32 & 9 & 37 \\
\hline Soils of Ograzhden Mountain ${ }^{[9,10]}$ & 19 & 103 & 41 & 371 & 45 & 6 & 36 \\
\hline Soils of Osogovo Mountain & 91 & 126 & 141 & 457 & 66 & 13 & 41 \\
\hline
\end{tabular}

Table. 3 Average content of heavy metals in rock groups in Bulgaria $(\mathrm{mg} / \mathrm{kg})$

\begin{tabular}{lcccccccc}
\hline Rock groups & $\mathbf{C u}$ & $\mathbf{Z n}$ & $\mathbf{P b}$ & $\mathbf{M n}$ & $\mathbf{N i}$ & $\mathbf{C o}$ & $\mathbf{C r}$ \\
\hline Rocks in Bulgaria & 32 & 53 & 26 & 743 & 77 & 16 & 108 \\
Acidic igneous rocks in Bulgaria & 8 & 28 & 30 & 370 & 6 & 3 & 8 \\
Acidic metamorphic rocks in Bulgaria & 20 & 50 & 20 & 287 & 10 & 11 & 34 \\
\hline
\end{tabular}

The first spectrum (fig. 1) illustrates the concentration and the dispersion of microelements in the lithosphere, the soils in the world and in Europe as well as the soils in the Osogovo Mountain. It displays the accumulated association of heavy metals $(\mathrm{Pb}$, $\mathrm{Cu}, \mathrm{Zn}, \mathrm{Ni}$, and $\mathrm{Co}$ ) in the soils of the mountain. Only $\mathrm{Mn}$ and $\mathrm{Cr}$ have values related to clarke dispersion (CD) about 2. The outlined association is related to the mineral content of the existing ore deposits in the mountain $[2,1]$, to the igneous and the metamorphic rocks, and to the soil-forming processes in the high altitudes.

One of the tasks of the research is the determination of the natural geochemical background of the landscapes considering the local petrochemical influence. A geochemical spectrum (fig. 2) displays the average content of heavy metals in the soils of the Osogovo Mountain compared to the average content of the soils in Bulgaria. The value of soils of Bulgaria represents the whole territory of the country while the value of the soils of Bulgaria (natural background) is related only to the landscapes in conservation zones (reserves, national parks, etc.). Generally, almost the same association of heavy metals is outlined as concentrated (except Co). $\mathrm{Mn}, \mathrm{Cr}$, and $\mathrm{Co}$ are with similar levels of dispersion. This comparison is another proof for the specific geochemistry of the rock complexes in the investigated mountain and their influence on the chemical content of the soil. 




Figure 1. Geochemical spectrum of soils in the world, in Europe, and in the Osogovo Mountain

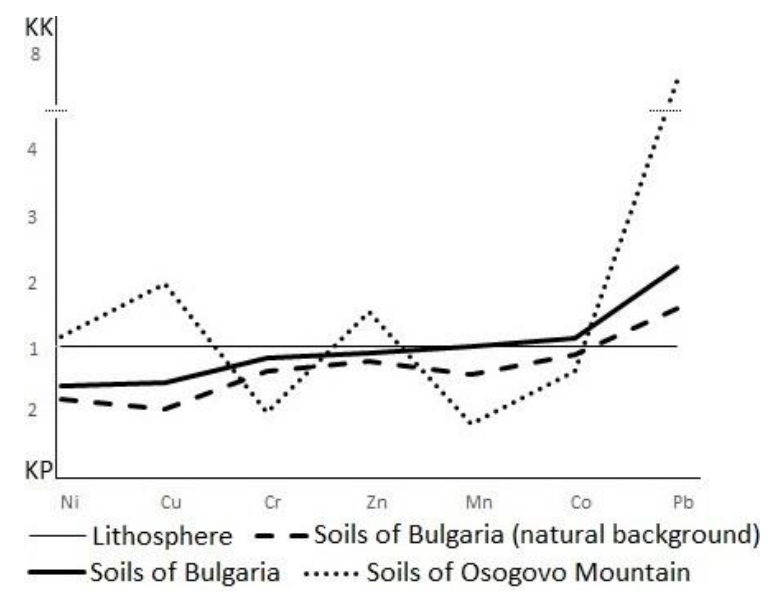

Figure 2. Geochemical spectrum of soils in Bulgaria, in Bulgaria (natural background), and in the Osogovo Mountain

The results in the Osogovo Mountain are a base for a comparative analyze to other neighboring mountains on the border between Bulgaria and North Macedonia that where investigated earlier (Vlahina Mountain, Maleshevska Mountain, and Ograzhden Mountain). The geochemical spectrum (fig. 3) displays variations of clarke concentration and clarke dispersion for heavy metals in the researched mountains. The values for $\mathrm{Pb}$ (CC over 8) and zinc (CC about 2) are highest in the Osogovo Mountain. The geochemical status of Osogovo Mountain is relatively close to the that in the Vlahina Mountain. The other investigated chemical elements have relevant and correlated values in all of these mountains. 


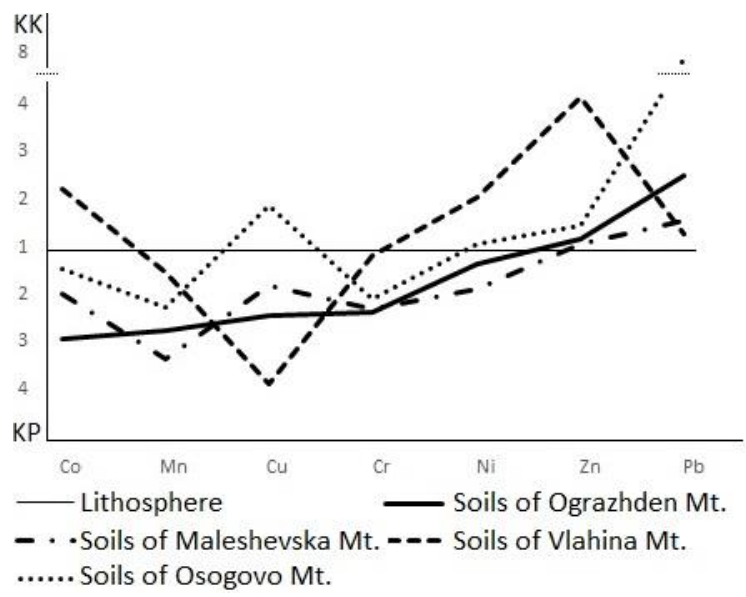

Figure 3. Geochemical spectrum for soils in mountains in South West Bulgaria

The technogenic geochemical influence is mostly visible in the analysis obtained from the soil substrate in the tailings dam around village of Gyueshevo (Table 1). The content of $\mathrm{Pb}, \mathrm{Zn}$, and $\mathrm{Mn}$ is relatively high and it is a probable consequence of technogenic impact on the landscapes. The high acidity and the open-air dried tailings dam are factors for heavy metals' contamination of landscapes in the area around via either water or air streams.

The radial differentiation of microelements in the soil profile of Cambisols in a beech forest at altitude of $1300 \mathrm{~m}$ shows the higher concentration of $\mathrm{Zn}$ and $\mathrm{Cu}$ in $\mathrm{A}$ horizon than in $\mathrm{B}$ and $\mathrm{C}$ horizons (Table 1). The other elements have relatively equal distribution in the profile.

\section{CONCLUSION}

The conducted geochemical research of the soil displays the special distribution of heavy metals' content in the Osogovo Mountain's landscapes. The results show the concentration and the dispersion values of heavy metals in the mountain in comparison to other geographical areas. There is well-defined association of concentrated microelements $(\mathrm{Pb}, \mathrm{Cu}, \mathrm{Zn}, \mathrm{Ni}$, and $\mathrm{Co})$ in the soils of the mountain due to the local petrology. Some areas of the mountain are impacted by mining and there are concentrations that certify the human impact on the geochemical structure of the landscapes in the mountain.

\section{REFERENCES}

[1] Atanasov, B. Geological Object "Osogovo", Bulgaria, 2016 http://beamkn.info/bg/index.php/en/lyubopitno/58-geolozhki-obekt-osogovo, on 1.02.2019

[2] Dimitrov, R., N. Vardev, O. Vitov, V. Georgiev. Ore formations in the Osogovo-Milevski region/Рудни формации в Осоговско-Милевския регион. Journal of Bulgarian geological society, vol. 57., book 1, Bulgaria, 1996, pp. 35-46

[3] Kuykin, S., I. Atanasov, Y. Hristova, D. Hristov. Background content of heavy metals and arsenic in the soil-forming rocks in Bulgaria/Фонови съдържания на тежки метали и арсен в почвообразуващите скали в България //Journal of Soils Science, Agrochemistry and Ecology. Vol. 36. № 1. Bulgaria, 2001, pp. 3-13.

[4] Mirchev, S. Chemical content of soils in Bulgaria/Химичен състав на почвите в България, Bulgaria, 1971. 
[5] Penin, R. Geochemical evaluation of the landscapes in natural conservation territories of South West Bulgaria/Ландшафтно-геохимическая оценка заповедных территории Югозападной Болгарии, PhD thesis, USSR, 1989.

[6] Penin, R. Geochemical research of the landscapes in the Tsarna River catchment in the Osogovo Mountain/Ландшафтно-геохимични изследвания в басейна на р. Църна Осоговска планина. Yearbook of Sofia University, book 2 - Geography, vol. 85. Bulgaria, 1994, pp 227-247.

[7] Penin, R. A study guide for geochemistry of landscapes/Ръководство по геохимия на ландшафтите, Sofia University Press, Bulgaria, 1997, pp. 23-34.

[8] Penin, R, Geochemistry of landscapes as a prioritized branch of science for detecting and solving environmental issues/Геохимията на ландшафтите -приоритетно научно направление при разкриване и решаване на екологични проблеми. An anniversary book: 30 years of Department "LEEP”, Bulgaria, 2003, pp. 46-52.

[9] Penin, R., D. Zhelev, T. Stoilkova. Ecogeochemical research of the landscapes in the Ograzhden Mountain (South West Bulgaria)/Екогеохимични проучвания на ландшафтите в планината Огражден (Югозападна България), Yearbook of Sofia University, book 2 Geography, vol. 109, Bulgaria, 2016, pp 105-116.

[10] Penin, R., D. Zhelev, T. Stoilkova, L. Semerdzhieva, D. Hristova. Geochemical research of the soils in the ladnscapes of the Belasitsa Mountain. Yearbook of Sofia Universtiy, book 2 Geography. Volume 111, Bulgaria, 2018, pp. 117-130.

[11] Perelman, A. Geochemistry of landscapes/Геохимия ландшафта, USSR, 1975, pp. 48.

[12] Salminen, R. (ed.). Geochemical Atlas of Europe. Part 1: Background Information, Methodology and Maps. Espoo, Geological Survey of Finland, Finland, 2005.

[13] Todorov, N. R. Penin, M. Konteva, Z. Cholakova, T. Stoilkova. Spacial structure and geoecological issues in the landscapes of Maleshevska Mountain/Пространствена структура и геоекологични проблеми на ландшафтите в Малешевска планина, Yearbook of Sofia Un., book 2 - Geography, vol. 108. Bulgaria, 2015. pp. 121-136.

[14] Todorov, N., R. Penin, Z. Cholakova, M. Konteva, T. Stoilkova. Peculiarities of the contemporary landscapes in the southern part of Vlahina Mountain/Особености на сьвременните ландшафти в южната част на Влахина планина. Yearbook of Sofia Un., book 2 - G., vol. 107, Bulg., 2014, pp. 115-127.

[15] Velchev, A., N. Todorov, K. Kostadinov. Evolution and contemporary status of the subalpine landscapes in the Osogovo Mountain/Развитие и съвременно състояние на субалпийските ландшафти в Осоговска планина. Yearbook of Sofia University, book 2 - Geography, vol. 85, Bulgaria, 1994, pp 81-199.

[16] Vinogradov, A. Average content of chemical elements in the many types of rocks in the crust/Среднее содержание элементов в главных типах изверженных горных породземной коры. USSR, 1962, pp. 34. 